\title{
Testicular Parameters and Sperm Morphology of Chinchilla Rabbit Fed With Different Planes of Soymeal
}

\author{
Parámetros Testiculares y Morfología Espermática del Conejo Chinchilla Alimentado con Diferentes \\ Productos de Soya
}

Oyeyemi Matthew Olugbenga \& Okediran Babatunde Samuel

OYEYEMI, M. O. \& OKEDIRAN, B.S. Testicular parameters and sperm morphology of chinchilla rabbit fed with different planes of soymeal. Int. J. Morphol., 25(1):139-144, 2007.

SUMMARY: The testicular parameters and sperm morphology were studied in twenty healthy Chinchilla breed bucks of rabbits fed with different planes of soybean meal. Their ages were between 6 to 10 months with their weights ranging from 1.4 to $1.9 \mathrm{~kg}$. The same quality of feeds was fed to each group throughout the study and at the rate of $0.5 \mathrm{~kg} / \mathrm{head} / \mathrm{day}$. The feeds contained graded percentage of soybean meal and growers mash.

Semen used in this study was from the caudal epididymides while morphological aberrations were determined from a total count of 400 spermatozoa in smears obtained with Wells and Awa stain.

Results of the spermiogram showed that the colour and consistency of the semen appreciated as the percentage of soybean meal increased. Group D with $90 \%$ soybean meal was significantly higher $(\mathrm{P}<0.05)$ over and above the values of other groups. Group D had a significant increase $(\mathrm{P}<0.05)$ over and above values of other groups in terms of percentage live spermatozoa. Semen concentration increased from $1.20 \pm 1.56 \times 10^{6} / \mathrm{ml}$ in group B with $30 \%$ soymeal to $2.00 \pm 2.67 \times 10^{6} / \mathrm{ml}$ in group D with $90 \%$ soymeal. Testicular parameters also showed that there was more weights increase as the percentage of soymeal in the feed increased.

It is therefore concluded and recommended that soymeal can be part of normal diet of Chinchilla Rabbit without any adverse effect on the reproductive potential of the male rabbit.

KEY WORDS: Chinchilla Rabbit; Soymeal; Morphology; Testicular parameters; Spermatozoa.

\section{INTRODUCTION}

Rabbit can be successfully raised on an unlimited green food, roots and hays while the addition of some grain cake food is always of some advantage. These feeds include hay, succulent, starches and grain, supplements, mineral salt, pelleted feed and water (Lebas et al., 1997; NAERLS, 1984). A series of complex processes is involved in male reproduction. These processes are controlled by hormones and the central nervous system. The activity of the hormone and the accessory glands is influenced directly or indirectly by heredity (Cohen \& Tissot, 1974), ambient temperature (Vogler et al., 1993) photoperiod and nutrition (Hafez, 1987; Adams \& Sign, 1981).

The plane of nutrition given to an animal can affect libido and quality of semen produced (Adams \& Sign;
Cameron \& Blackshaw, 1980). It also affects age of attaining puberty and stimulation of the hypothalamus indirectly to produce interstitial cell stimulating hormone that acts in the testicular tissue (Adams \& Sign; Kellog et al., 1949; Cogan et al., 1968).

Soybean seeds contain approximately $36 \%$ protein and $18 \%$ fat. After extraction the meal may have as much as $45 \%$ proteins and $1-5 \%$ fat. Soybean meal was found to be $6.8 \%$ more efficient than peanut meal (Kellog et al. But some Scientists, cautioned that untreated cottonseed meal should not be used as a suitable replacement for soybean meal as it contains gossypol, a substance toxic to rabbit. Soybean meal appears to be the most satisfactory protein supplement for rabbit (Gaman \& Fisher, 1970). 
There are, however, a number of factors affecting these reproductive parameters or fertility in animals. Such factors include age, nutrition, environment, health status or disease, frequency of use, management and congenital abnormalities (Hughes \& Varley, 1980; Oyeyemi et al., 2000). Abnormalities in the development of the testes can lead to infertility such as primary spermatozoa abnormalities (Moss et al., 1979). While Paufler et al., (1969) reported effects of nutrition on the testicular parameter in life rabbit. There appears to be no information available on the effect of soymeal on male reproduction.

The aim of this study was to determine the effects of different planes of soybean meal (soyameal) on the testicular parameters and sperm morphology of male rabbit. It is hoped that such information will be a useful guide in andrological studies, semen extension and artificial insemination programme in the rabbit.

\section{MATERIAL AND METHOD}

Animal management. Twenty healthy Chinchilla breed buck of rabbits aged from 6-10 months with masses or weights of 1.4 to $1.9 \mathrm{~kg}$ were used in this study. They were randomly assigned to four groups of five bucks per group. All animals were clinically examined and confirmed to be free from any obvious abnormalities of the palpable reproductive organs. They were kept in cages in the Experimental Animals Unit of the Faculty of Veterinary Medicine, University of Ibadan, Nigeria.

During stabilization, routine medications consisted injecting oxytetracyline ${ }^{\circledR}$ (Laboratory Hipra S. A. Spain) at a dose rate of $1.0 \mathrm{ml} / 10 \mathrm{~kg}$ body weight, and deworming with Albendazol ${ }^{\circledR}$ (Phenix, Belgium) at a dosage of $2 \mathrm{ml} / 10 \mathrm{~kg}$ body weight. Animals were weighed weekly using a spring balance, andscrotal circumference was determined at the widest part of the scrotum weekly. Fresh water was provided ad libitum.

These bucks were stabilized for four weeks before the commencement of the experiment. They were all fed growers mash with varying percentages of soymeal as follows:

Group A $\quad 0 \% \quad$ Soymeal $\quad 100 \%$ Growers mash Group B $\quad 30 \% \quad$ Soymeal $\quad 70 \%$ Growers mash Group C $\quad 60 \% \quad$ Soymeal $\quad 40 \%$ Growers mash Group D $\quad 90 \% \quad$ Soymeal $\quad 10 \%$ Growers mash

Experiment. The same quantity of feeds was fed to each group throughout the experimental studies at the rate of
$0.5 \mathrm{~kg} / \mathrm{head} / \mathrm{day}$. Subsequently, orchidectomy was performed after local intra-testicular anaesthesia with an injection of $1.0 \mathrm{ml}$ of xylocaine (Astra, Kings Langley, England) by open castration method. A midline or pre-scrotal incision was made; the testicles were milked out of the incision site. The testicles were exposed by incising the Tunica vaginalis. The spermatic cord was exposed, ligated and incised. The subcutaneous tissues were closed with $3^{\circ}$ catgut and the skin with nylon suture. The circumference and length of the castrated testis, weight of testis epididymis together, weight of testis alone and weight of epididymis alone were determined.

Semen collection. Semen samples were collected from caudal epididymides. The samples were analyzed routinely as soon as they were collected. Colour and consistency were determined by visual assessment and sperm concentrations were determined using the improved Neubauer haemocytometer after dilution in $0.05 \%$ formol-saline. Mass activity of the spermatozoa; progressive motility, percentage live and spermatozoa morphology were determined by conventional methods (Zemjanis, 1977).

Morphological aberrations were determined from a total count of 400 spermatozoa in smears obtained with Wells and Awa stains. While Nigrosin and Eosin stains was used to determine the percentage live count. Sperm abnormalities were classified by method described by Bloom (1973).

\section{RESULTS}

Effects of different planes of soymeal can be seen in the spermiogram studied (Table I). The colour of the ejaculates were creamy white at the onset of the treatment but became creamy as the percentage of soymeal increased. There was increase in progressive motility with increase in percentage of soymeal with the value of Group D (90\% soymeal) significantly higher $(\mathrm{P}<0.05)$ than that of Group A ( $0 \%$ soymeal). Group A with $0 \%$ soymeal had superior value of percentage live spermatozoa when compared with Group B (30\% soymeal). Nevertheless, there was a progressive increase from Groups B - D.

The effects of the different planes of soymeal on the testicular parameters are as presented in Table II. The morphological aberrations as per the effects of the planes of soymeal are presented in Table III. The primary abnormalities showed $5.0 \%, 8.5 \%, 8.0 \%$ and $8.0 \%$ abnormalities for Groups A - D respectively while the tertiary abnormalities were $28 \%, 22.5 \%, 17.5 \%$ and $13.5 \%$ for Groups A - D respectively. 
Table I. Spermiogram of Chinchilla Rabbit at different planes of Soymeal.

\begin{tabular}{lcccc}
\hline Semen characteristics & $\begin{array}{c}\text { GROUP A } \\
\text { 0\% Soymeal }\end{array}$ & $\begin{array}{c}\text { GROUP B } \\
\mathbf{3 0 \%} \text { Soymeal }\end{array}$ & $\begin{array}{c}\text { GROUP C } \\
\text { 60\% Soymeal }\end{array}$ & $\begin{array}{c}\text { GROUP D } \\
\text { 90\% Soyameal }\end{array}$ \\
\hline Ejaculate Colour & Creamy white & Creamy & Creamy & Creamy \\
Progressive Motility & $68.3 \pm 24.10$ & $80.0 \pm 10.00$ & $80.0 \pm 10.00$ & $86.6 \pm 7.41$ \\
Wave Motion $(+-+++)$ & ++ & +++ & +++ & +++ \\
Percentage Live Spermatozoa & $86.6 \pm 8.50$ & $70.0 \pm 6.70$ & $80.0 \pm 5.56$ & $83.3 \pm 1.7$ \\
Semen Concentration $(10 \% / \mathrm{ml})$ & $1.37 \pm 2.94$ & $1.20 \pm 1.56$ & $1.80 \pm 2.57$ & $2.00 \pm 2.67$ \\
\hline
\end{tabular}

Table II. Effect of Planes of soymeal on the testicular parameter of Chinchilla rabbit.

\begin{tabular}{lcccc}
\hline S emen characteristics & $\begin{array}{c}\text { GROUP A } \\
\text { 0\% Soymeal }\end{array}$ & $\begin{array}{c}\text { GROUP B } \\
\text { 30\% Soymeal }\end{array}$ & $\begin{array}{c}\text { GROUP C } \\
\text { 60\% Soymeal }\end{array}$ & $\begin{array}{c}\text { GROUP D } \\
\text { 90\% Soyameal }\end{array}$ \\
\hline Weight of testis and epididymis (g) - Right & $2.38 \pm 0.10$ & $2.65 \pm 0.06$ & $2.42 \pm 0.21$ & $2.75 \pm 0.01$ \\
Weight of testis and epididymis (g) - Left & $2.53 \pm 0.01$ & $2.63 \pm 0.06$ & $2.77 \pm 0.71$ & $2.78 \pm 0.03$ \\
Weight of testis (g) - Right & $1.40 \pm 0.02$ & $1.73 \pm 0.06$ & $1.47 \pm 0.05$ & $1.77 \pm 0.03$ \\
Weight of testis (g) - Left & $1.80 \pm 0.07$ & $1.80 \pm 0.03$ & $1.50 \pm 0.03$ & $1.90 \pm 0.01$ \\
Weight of epididymis (g) - Right & $0.90 \pm 0.05$ & $0.93 \pm 0.03$ & $0.95 \pm 0.05$ & $0.98 \pm 0.01$ \\
Weight of epididymis (g) - Left & $0.97 \pm 0.01$ & $0.89 \pm 0.01$ & $0.90 \pm 0.06$ & $0.97 \pm 0.02$ \\
Volume of testis (ml) - Right & $1.20 \pm 0.06$ & $1.90 \pm 0.03$ & $1.47 \pm 0.04$ & $1.47 \pm 0.01$ \\
Volume of testis (ml) - Left & $1.67 \pm 0.02$ & $2.00 \pm 0.01$ & $1.27 \pm 0.04$ & $1.58 \pm 0.01$ \\
Volume of epididymis (ml) - Right & $0.08 \pm 0.06$ & $1.27 \pm 0.06$ & $1.03 \pm 0.01$ & $0.85 \pm 0.03$ \\
Volume of epididymis (ml) - Left & $0.93 \pm 0.01$ & $1.02 \pm 0.01$ & $1.13 \pm 0.03$ & $0.87 \pm 0.03$ \\
Scrotal circumference (cm) & $6.47 \pm 0.08$ & $5.97 \pm 0.07$ & $6.30 \pm 0.26$ & $6.73 \pm 0.03$ \\
\hline
\end{tabular}

Table III. Morphological characteristics of spermatozoa of Chinchilla rabbit at different planes of soymeal.

\begin{tabular}{|c|c|c|c|c|c|c|}
\hline CLASSIFICATION & PARAMETERS & $\begin{array}{c}\text { GROUP A } \\
\text { 0\% }\end{array}$ & $\begin{array}{c}\text { GROUP B } \\
\text { 30\% }\end{array}$ & $\begin{array}{l}\text { GROUP C } \\
60 \%\end{array}$ & $\begin{array}{c}\text { GROUP D } \\
90 \%\end{array}$ & TOTAL \\
\hline \multirow{6}{*}{$\begin{array}{c}\text { PRIMARY } \\
\text { ABNORMALITIES }\end{array}$} & Twin head & 0 & 0 & 0 & 0 & $0(0)$ \\
\hline & Dag defect & 3 & 2 & 3 & 3 & $11(1.37)$ \\
\hline & Abnormal head & 7 & 8 & 7 & 8 & $30(3.75)$ \\
\hline & $\begin{array}{l}\text { Proximal cytoplasmic } \\
\text { droplet }\end{array}$ & 0 & 5 & 3 & 1 & $9(1.12)$ \\
\hline & $\begin{array}{l}\text { Distal cytoplasmic } \\
\text { droplet }\end{array}$ & 0 & 2 & 3 & 4 & $9(1.12)$ \\
\hline & Total & $10(5.0)$ & $17(8.5)$ & $16(8.0)$ & $16(8.0)$ & $59(7.37)$ \\
\hline \multirow{5}{*}{$\begin{array}{c}\text { SECONDARY } \\
\text { ABNORMALITIES }\end{array}$} & Tail coiled around head & 4 & 6 & 5 & 4 & $19(2.37)$ \\
\hline & $\begin{array}{l}\text { Tail coiled around mid } \\
\text { piece }\end{array}$ & 1 & 3 & 5 & 8 & $17(2.12)$ \\
\hline & Tail coiled below & 3 & 3 & 2 & 2 & $10(1.25)$ \\
\hline & Stumpy tail & 4 & 4 & 3 & 4 & $15(1.87)$ \\
\hline & Total & $12(6.0)$ & $16(8.0)$ & $15(7.5)$ & $18(9.0)$ & $61(7.62)$ \\
\hline \multirow{4}{*}{$\begin{array}{c}\text { TERTIARY } \\
\text { ABNORMALITIES }\end{array}$} & Detached head & 45 & 33 & 16 & 15 & $109(13.62)$ \\
\hline & Simple bent tail & 10 & 9 & 14 & 9 & $42(5.25)$ \\
\hline & Simple coiled tail & 1 & 3 & 5 & 3 & $12(1.50)$ \\
\hline & Total & $56(28.0)$ & $45(22.5)$ & 35 (17.5) & 27 (13.5) & $163(20.37)$ \\
\hline $\begin{array}{l}\text { TOTAL NUMBER OF } \\
\text { SPERM CELLS }\end{array}$ & & $400(100)$ & $400(100)$ & $400(100)$ & $400(100)$ & $1600(100)$ \\
\hline $\begin{array}{l}\text { TOTAL NUMBER OF } \\
\text { ABNORMAL SPERM } \\
\text { CELLS }\end{array}$ & & $\begin{array}{c}78 \\
(19.50)\end{array}$ & $\begin{array}{c}78 \\
(19.50)\end{array}$ & $\begin{array}{c}66 \\
(16.50)\end{array}$ & $\begin{array}{c}61 \\
(15.25)\end{array}$ & $\begin{array}{c}283 \\
(17.69)\end{array}$ \\
\hline $\begin{array}{l}\text { TOTAL NUMBER OF } \\
\text { NORMAL SPERM } \\
\text { CELLS }\end{array}$ & & $\begin{array}{c}322 \\
(80.50)\end{array}$ & $\begin{array}{c}322 \\
(80.50)\end{array}$ & $\begin{array}{c}324 \\
(83.50)\end{array}$ & $\begin{array}{c}339 \\
(84.75)\end{array}$ & $\begin{array}{c}1317 \\
(82.31)\end{array}$ \\
\hline
\end{tabular}


In primary abnormalities, the value of Group $B$ $(8.5 \%)$ was higher $(\mathrm{P}>0.05)$ than Groups $\mathrm{A}, \mathrm{B}$, and $\mathrm{D}$. secondary abnormalities value for Group D was significantly higher $(\mathrm{P}<0.05)$ than Group $\mathrm{A}$. The value of tertiary abnormalities in Groups B, C, and D were about the same but significantly lower $(\mathrm{P}>0.05)$ than Group A.

In general, the total percentages of abnormal sperm cells decrease as the percentage of soymeal increases.

\section{DISCUSSION}

In this study, the colour of the ejaculate was creamy to creamy-white in all the treatments. The unidirectional progressive movement (motility) increases as the percentage of the soymeal increases. It is observed that high level of protein and fat in the soymeal in this treatment or study has a positive effect on the motility of the spermatozoa. This is in agreement with other scientists (Oyeyemi et al., 1998; Hughes \& Varley) that adequate nutrition with high percentages of protein will encourage the motility and the concentration of spermatozoa.

The swirl or wave motion increases as the percentage of soymeal increases $(++$ to +++$)$. It also agreed with earlier observation that the spermatozoa having more energy (fructose) will move within the medium rapidly and for a long time. The planes of soymeal except in Group B did not significantly affect the percentage live spermatozoa (spermatozoa livability), another parameter in the determination of viability and fertility of animals.

Semen concentration in this study increases with the increasing level of soymeal. This indicates that there is possibility of higher fertility rate by the reason of the number of spermatozoa available at the time of copulation or insemination. This study on the effect of planes of soymeal on testicular parameter shows that capacity of the testes increases with increasing percentage of soymeal thus increasing capacity to produce sperm cells (spermatogenesis). This agrees with Paufler et al. and Oyeyemi et al., (2002) that the higher the testicular value (without any abnormality) the higher the capacity of the cells during spermatogenesis. Morris et al., (1999) discovered that within a species of animals there is a good correlation between spermatozoa production, testicular sizes and the age of the animal. Another Scientist, Skinner (1975) agrees with the fact that as the testicular size increases, there is increase in spermatozoa production.

Morphological characteristics in this study show that primary abnormalities in the group without soymeal were quite low when compared to other groups with soymeal. The percentage of abnormalities was less than the upper limit of $20 \%$ recommended as the minimum for good reproductive potential and fertility in either normal mating and or in artificial insemination (Zemjanis).

The plane of soymeal did not influence any significant change $(\mathrm{P}>0.05)$ in the percentage of abnormalities in secondary abnormalities. The low incidence of secondary abnormalities as observed implies soymeal encourages a high functional integrity of the epididymis (Awojobi \& Oyeyemi, 2001). The percentage of tertiary abnormalities was decreasing as the plane of soymeal was increasing. The process of staining and handling (cold and heat stress) may influence or may be responsible for higher value in this study.

In general, total abnormalities per group or as per total sperm cells in all the groups were within normal range and show that increasing plane of soymeal decreases the number of abnormal sperm cells in Chinchilla rabbit. Increase in protein and energy encourage growth rate and maintain body weight thus capacity to copulate and fertilize (Schiere, 1999; Adams \& Sign).

In conclusion, the fertility capacity is increased with the increasing percentage of motility, percentage livability and semen concentration without increasing in abnormal sperm cells; it is therefore concluded and recommended that soymeal can be part of normal diet or feeds of male chinchilla rabbits without any adverse effect on the reproductive performance of the male animal.

\section{REFERENCES}

Adams, C. E \& Sign, M. M. Semen Characteristics and fertility of Rabbits subjected to exhaustive use. Laboratory Animal, 15:157-61, 1981.

Awojobi, H. A. \& Oyeyemi, M. O. Morphological changes in Epididymal spermatozoa of Red Sokoto (Maradi) Bucks Nigerian Journal Animal Production. 28 (2):20710, 2001.

Bloom, E. The ultrastructure of some characteristic sperm defects. Nord. Veterinary Medicine, 25:283, 1973.

Cameron, R. D. A \& Blackshaw, W. The effect of elevated ambient temperature on spermatogenesis in the boar. $J$. Reproduction and fertility 173-179, 1980. 
OYEYEMI, M. O. \& OKEDIRAN, B. S. Parámetros testiculares y morfología espermática del conejo chinchilla alimentado con diferentes productos de soya. Int. J. Morphol., 25(1):139-144, 2007.

RESUMEN: Se estudiaron los parámetros testiculares y la morfología espermática de 20 chinchillas sanas, alimentadas con diferentes raciones de soya. Sus edades estuvieron entre 6 y 10 meses con pesos que fluctuaban entre 1,4 y 1,9 kg. Se dió la misma calidad de alimentación a cada grupo y recibieron $0,5 \mathrm{~kg}$ por día cada una de ellas. El alimento contenía porcentajes graduados de soya y de grano molido.

El semen usado en este estudio provino de la parte caudal del epidídimo, mientras que las observaciones morfológicas fueron determinadas desde un conteo total de 400 espermatozoides teñidos a través de técnica de Wells \& Awa.

Los resultados del espermiograma mostraron que el color y la consistencia del semen se incrementó cuando hubo mayor concentración de soya en el alimento. El grupo D con $90 \%$ de concentración de soya fue estadísticamente significativo $(p<0,05)$, sobre los valores de los otros grupos. El grupo D tuvo un incremento significativo $(p<0,05)$ sobre los valores de los otros grupos en términos de porcentaje de vida de los espermios. En el grupo B con 30\% de soya en su alimento. La concentración de semen fue de 1,2 $\pm 1,56 \times 10 \% / \mathrm{ml}$ y en el grupo D con un $90 \%$ de soya fue de 2,0 2 2,67 x 10\% $/ \mathrm{ml}$. Los parámetros testiculares también mostraron que hubo incremeento en el peso cuando se alimentaron con mayor porcentaje de soya.

Concluimos y recomendamos que la soya se parte de la dieta normal de la chinchilla sin ningún efecto adverso sobre el potencial reproductivo de la hembra.

PALABRAS CLAVE: Conejo chinchilla; Soya; Morfología; parámetros testiculares; Espermatozoide.

Cogan, U.; Yaron, Z. Brek \& Zimmermen, G. Effect of processing conditions on nutritive value of isolated Soyabean protein. J. Agriculture Food Chemistry, 16:196-8, 1968.

Cohen, C. \& Tissot, R. G. Serological genetics. In: Weisbroth S. H.; Flatt, R. F. \& Kraus, A. L. (eds). The Biology of laboratory Rabbits. Academic Press. New York, 1974. Chapter 7, p167.

Gaman, E. \& Fisher, H. The essentiability of arginine, lysine and methionine for the growing Rabbit. Nutrition and Reproduction inter. 1:57-64, 1970.

Hafez, E. S. E. Advances in reproduction biology semen's evaluations In: Reproduction in farm animals. 5th ed., 1987.

Hughes, P. E. \& Varley, M. A. Factors affecting male fertility. In: Reproduction in the Pig. 1980. p. 191.

Kellog, C. E; Templeton, G. S. \& Suitor, A. E. Feed required to produce six-pound rabbits after weaning and conditions affecting their carcass grade and cuts. U.S., Dep Agr. Circ. 1949.

Lebas, F.; Coundent, P.; de Rochambeau, H. \& Thebault, R. G. The Rabbit: husbandry, health and production (new revised version). Food and Agriculture organization of the United Nations, 1997. pp. 205.
Morris, O. L.; Smith, M. F.; Parrish, W. R.; William, J. D. \& Wilbank, J. N. The effect of scrotal circumference, libido and semen quality on fertility of American Brahaman and Santa Certudies Bull. Proceeding of Animal Management of the Society for Theriogenology. Oklahoma City, 1979.

Moss, J. A.; Melrose, D. R.; Reed, H. C. B. \& Vandeplassche, M. Spermatozoa, Semen and Artificial Insemination In: fertility and infertility in domestic animals. Edited by J. A. Laing 3rd. Ed. Bailliere Tindal London, 1979. pp. 59-91.

NAERLS. National Agricultural Extension and Research Services, Ahmadu Bello University, Zaria Nigeria Livestock Farmers, 1984. V. 2. p.10.

Oyeyemi, M. O.; Oke, A. Olusola; Ajala, O. Oluwatoyin \& Idehen, C. O. Differences in testicular parameters and morphological characteristics of spermatozoa as related to age of West African Dwarf bucks. Tropical Journal Animals Science, 5 (1): 99-107, 2002.

Oyeyemi, M. O.; Ajala, O. O.; Akusu, M. O. \& Agbesola, O. O. Effects of Starvation on semen characteristics of West African dwarf bucks. Conference of Animal science Association Nigeria 22-24, 1998 Lagos, Nigeria, 1998. pp 128-30.

Oyeyemi, Matthew O.; Akusu, Matthew O. \& Olufunke E. 
Ola-Davies. Effects of successive ejaculations on the spermiogram of West African dwarf goats (Capra hircus L). Veterinarski Arhiv., 70 (4):215-21, 2000.

Paufler, S.; Van Vleck, L. D. \& Foote, R. H. Estimation of testicular size in live Rabbits. Int. J. of fertility, 14(2):18891, 1969.

Schiere, J. B. Backyard Rabbit farming in the Tropics. Agrodok 20 third (revised) edition. 1999. 70pp.

Skinner, J. D. Reproductive physiology of indigenous and exotic male animal in South Africa. Agricultural Research ABA, 43:4628, 1975.

Vogler, C. J.; Bame, J. H.; Delarnelle, J. M.; Mc Gilliaro, M. L. \& Saacke, R. G. Effect of elevated temperature on morphological characteristics of ejaculated spermatozoa in the Bovine. J. of Theriogenology, 40(6):1207-19, 1993.

Zemjanis, R. Collection and evaluation of semen. In: Diagnostic and Therapautic techniques in Animal Reproduction. The Williams and Wilkins Co. Baltimore, 1977. pp 242.
Correpondence to:

Oyeyemi Matthew Olugbenga, DVM, MVPH, PhD, MCVSN Department of Veterinary Surgery and Reproduction Faculty of Veterinary Medicine

University of Ibadan, Ibadan

NIGERIA

Email: mo.oyeyemi@mail.ui.edu.ng

Received: 27-11-2006

Accepted: 26-12-2006 